\title{
Human Resources as Foundation for Innovational Potential and Strategic Competitiveness of Modern Enterprises
}

\author{
Lilia V. Ermolina1 \\ Oksana S. Chechina² \\ Alexandra V. Sultanova ${ }^{3}$ \\ ${ }^{1}$ Samara State Technical University, Lecturer of the Department of Industrial Economics, Samara, Russia \\ ${ }^{2}$ Samara State Technical University, Associate Professor of the Department of Industrial Economics, Samara, Russia \\ ${ }^{3}$ Ph.D. in Economics, Associate Professor, Chair of Economics and Management in Organization \\ FSBEI HPE“Samara State Technical University
}

\author{
Doi:10.5901/mjss.2016.v7n1p274
}

\section{Abstract}

The purpose of the article is to determine the role of human resources in formation of innovational potential and strategic competitiveness of modern enterprises, revelation of perspectives, and development of recommendations for perfection of management of human resources. The research methods include methods of evaluation of competitiveness of products and enterprise for allocating factors of competitiveness and determination of the role of human resources in formation of innovational potential and strategic competitiveness of modern enterprises, as well as methodology of SWOT-analysis for determination of perspectives of development of human resources in developing countries under the conditions of integration and globalization of the world economy. The authors determine the ratio of strategic competitiveness, innovational potential, and human resources under the modern economic conditions and determine the problems and perspectives of development of human resources in modern Russia. As a result of the research, a theoretical model of the Russian economy under the conditions of globalization and integration was built, and expedience of development of human resources in Russia and other developing countries for provision of strategic competitiveness of domestic enterprises was substantiated. The main conclusions of the research are proofs of the offered hypothesis and development of recommendations for development of human resources in developing countries by the example of modern Russia.

Keywords: human resources, innovational potential, strategic competitiveness, modern enterprises.

\section{Introduction}

Modern economy is based on the work of market mechanisms, which supposes competition between enterprises. In order to survive in competitive struggle, it is necessary to possess competitive advantages, as compared to other members of the market. However, speed of distribution and aging of information and technologies in the XXI century is very high, so competitive advantages are copied by rivals and cease to be advantages. Impossibility for preservation of market positions under the condition of using generally known and traditional tools cause the necessity for constant development of modern enterprises through creation and implementation of innovations (Popkova \& Tinyakova 2013a). While in mid-term, competitiveness can be ensured without innovations, innovations are necessary in order to preserve and, moreover, to increase strategic competitiveness of enterprise in long-term. This determines actuality of the research of factors of innovational potential and strategic competitiveness of modern enterprises. This research offers the hypothesis that one of the most important factors is human resources.

\section{Materials and Method}

There are two main approaches to determining the competitiveness of enterprise. The first approach is based on supposition that competitiveness of enterprise is competitiveness of its products. The supporters of this approach include (Acemoglu et al., 2014), (Berge et al., 2015), Ciobotaru \& Anghelută, 2014), (Lauder, 2015), and (Li et al., 2015), (Dhar, 2015), (Oh et al., 2015), (Cheng \& Chan, 2015), (Stone et al., 2015). This research offers to use the following formula for evaluation of competitiveness of enterprise's products:

$$
\mathrm{C}_{\text {prod }}=\text { Price / Quality + Brand }
$$


Cprod - competitiveness of enterprise's products;

Price - price of enterprise's products;

Quality - quality of enterprise's products;

Brand - brand of enterprise's products.

According to the second approach, competitiveness of enterprise is determined by effectiveness of its work and use of production factors - labor, land, and capital. At that, market share is a very important indicator. This approach is supported by (Manafi \& Subramaniam, 2015), (Perna et al., 2014), (Sverdlova, 2014), and (Ugheoke et al., 2015). The authors of this research offer to use the following formula for evaluation of enterprise's competitiveness:

$\mathrm{C}_{\text {enter }}=(\mathrm{Li}+\mathrm{Ci}+\mathrm{Ri}) *$ Market share

where $\mathrm{C}_{\text {enter }}-$ competitiveness of enterprise;

$\mathrm{Li}$ - labor intensity of production at specific enterprise;

$\mathrm{Ci}$ - capital intensity of production at specific enterprise;

$\mathrm{Ri}$ - resource intensity of production at specific enterprise;

Market share - enterprise's market share.

Both methodologies suppose comparison of indicators of the studied enterprise with indicators of rivals or model enterprise which is a leader in this market or the main rival for the studied enterprise. Also, calculations, as a rule, suppose score evaluation for simplification of calculations and provision of comparability of received values of competitiveness.

\section{Results}

Let us view the first approach to the evaluation of competitiveness of enterprise. Within this approach, provision of strategic competitiveness of enterprise supposes reduction of price, increase of quality, and strengthening of brand. The most important condition for price reduction with preservation of profitability of enterprise is reduction of production cost, which is possible by means of the following measures:

- use of cheaper resources and equipment, which is related to reduction of products' quality and contradicts the idea of its growth;

- reduction of wages or quantity of enterprise's employees, which is also related to reduction of products' quality and contradict the idea of its growth;

- implementation of new technologies into production and perfection of production process, which supposes realization of innovational ideas of enterprise's employees.

Increase of the quality of products is possible by means of the following measures:

- using resources and equipment of higher quality, which leads to the growth of enterprise's expenses and contradicts the idea of reduction of production cost;

- improvement of management quality which supposes strengthening of quality control at enterprise and stimulation of staff for manufacture of high-quality products;

- implementation of new technologies into production and perfection of production process, which supposes realization of innovational ideas of enterprise's staff.

It should be noted that the most effective tool for reduction of cost and increase of product quality of enterprise is implementation of process innovations by means of human resources - management of enterprise and its employees. Strengthening of brand supposes creation of product innovations for supporting consumers' interest in enterprise and its products.

Let us turn to the second approach to evaluation of competitiveness of enterprise. Within this approach, provision of strategic competitiveness of enterprise supposes increase of effectiveness of the use of production factors and increase of the enterprise's market share.

Increase of effectiveness of the use of production factors at enterprise supposes perfection of technology and implementation of process innovations, which is impossible without enterprise's human resources. Increase of enterprise's market share is possible by means of increase of competitiveness of its products or attraction of consumers' attention through issue of innovational products.

Thus, regardless of the approach to evaluation of strategic competitiveness of enterprise, it is based on innovational potential of enterprise, which is determined by its human resources. Therefore, increase of strategic competitiveness requires development of human resources of enterprise (Fig. 1). 


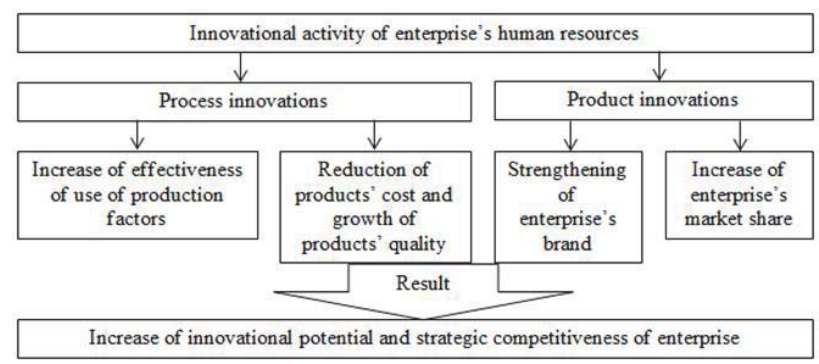

Figure 1. Graphical representation of innovational potential and strategic competitiveness of modern enterprise

However, while developed countries observe this rule and pay a lot of attention to development of their human resources through conduct of educational events and retraining, stimulation of creative activity of staff, and attraction of young and perspective employees to development of innovations (CRANET Survey..., 2014), the developing countries, which include Russia, show the opposite situation.

Russian enterprises want to use administrative barriers and monopolistic conspiracy for reduction of the competition level at the market, which, together with low effectiveness of anti-monopoly policy, leads to a high level of monopolization of most markets (Popkova et al., 2015a). Due to lack of competition, enterprises-monopolists do not increase the quality of products and increase their price, which influences consumers in negative way. потребители. Development of human resources is not paid enough attention, and they are viewed as workforce, not as the source of valuable knowledge and means for creation of innovations (Popkova \& Tinyakova 2013b).

Nevertheless, under the conditions of globalization and integration of countries into the world economy, there is an increase of competition in the markets of developing countries, including Russia. The Russian enterprises, which are used to functioning under the conditions of protectionism and monopoly, cannot compete with successful international companies, which leads to the threat to their strategic competitiveness (Popkova et al., 2015b). Therefore, there is objective necessity for implementation of innovations for supporting the strategic competitiveness of modern Russian enterprises, which is based - as was proved above - on human resources. Model of the Russian economy under the conditions of globalization and integrations is shown in Fig. 1.
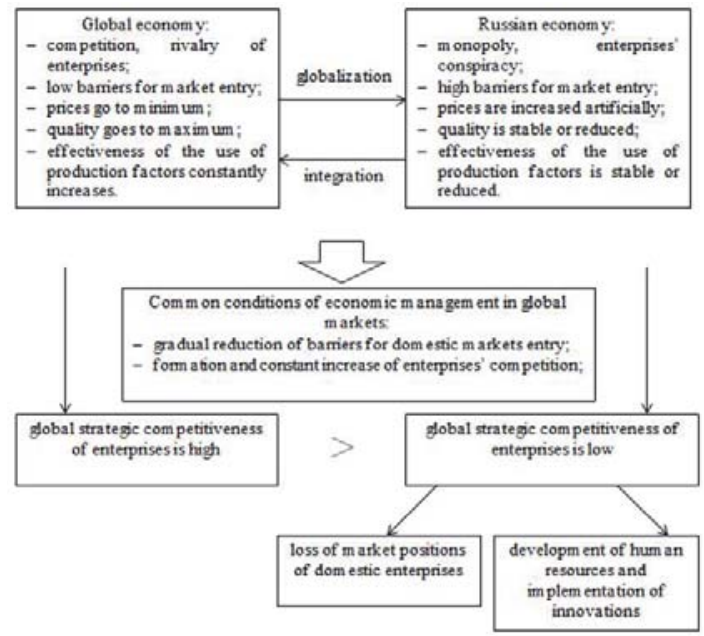

Figure 1. Model of Russian economy under the conditions of globalization and integration

As is seen from Fig. 1, under the common conditions of economic management in the global markets, Russian companies, which are not used to compete between themselves, face a high level of competition from foreign 
enterprises, which leads to two variants of development of events: loss of market positions of foreign enterprises and development of human resources and implementation of innovations (Popkova et al., 2013). SWOT-analysis of development of human resources in Russia under the conditions of integration and globalization of the global economy is shown in Table 1.

Table 1. SWOT-analysis of development of human resources in Russia under the conditions of integration and globalization of the world economy

\begin{tabular}{|l|l|}
\hline Strong sides of human resources in Russia & Weak sides of human resources in Russia \\
\hline $\begin{array}{l}\text { high level of population's education and availability of highly-qualified } \\
\text { staff }\end{array}$ & $\begin{array}{l}\text { non-conformity of educational programs to production } \\
\text { requirements }\end{array}$ \\
\hline creative thinking, which is a peculiarity of Russian mentality & $\begin{array}{l}\text { lack of investments for implementation of creative initiatives of } \\
\text { human resources }\end{array}$ \\
\hline significant excess of offer over demand in the labor market & weak material motivation of creative activity of human resources \\
\hline perspectives of development of human resources in Russia & threats to development of human resources in Russia \\
\hline $\begin{array}{l}\text { increase of demand in labor market due to increase of significance of } \\
\text { labor resources }\end{array}$ & $\begin{array}{l}\text { increase of competition in labor market from foreign human } \\
\text { resources }\end{array}$ \\
\hline $\begin{array}{l}\text { investing into implementation of creative initiatives of employees from } \\
\text { entrepreneurs }\end{array}$ & $\begin{array}{l}\text { toughening of requirements to selection of human resources from } \\
\text { employers }\end{array}$ \\
\hline high material motivation of creative activity & appreciation and reduction of accessibility of education \\
\hline
\end{tabular}

As is seen from Table 1, Russian human resources possess a lot of strong sides: high level of education and creative activity; however, their development is hindered by lack of demand and investments from business. Under the conditions of integration and globalization of the world economy, there arise large perspectives for development of human resources in Russia, as there is a growing demand for implementation of innovational potential of human resources for provision of strategic competitiveness of Russian enterprises.

Perspectives of development of human resources in Russia are related to increase of demand in labor market due to increase of significance of human resources, investments into realization of creative initiatives of employees from entrepreneurs, and high material motivation of creative activities. A threat to development of human resources in Russia is posed by strengthening of competition in the labor market from foreign human resources, tough requirements to selection of human resources from employers, high prices, and reduction of education's accessibility.

\section{Conclusion}

Thus, as a result of the conducted research, the offered hypothesis was proved, and it was revealed that human resources are the basis of innovational potential and strategic competitiveness of modern enterprises. At present enterprises of developed countries realize this and, being in the situation of strong market competition, actively develop their human resources. At the same time, in developing countries, the level of competition is, as a rule, lower, which leads to absence of necessity for competition and implementation of innovations, so companies do not pay enough attention to development of human resources.

Under the influence of the processes of globalization and integration, common economic conditions are formed for developed and developing countries. This situation is observed in modern Russia. In order to struggle in global competition, Russian companies have to adapt to new conditions and develop their human resources. Perspective directions of development of human resources for the increase of innovational potential of Russian enterprises and provision of their strategic competitiveness under the conditions of globalization and integration include the following:

- development of new educational programs on the basis of experience of representatives of real companies supposes joint activities of future employers and representatives of educational establishments for development of educational programs;

- motivation and stimulation of innovational activity of human resources - requires provision of bonuses for innovation-active employees of enterprises;

- creation of favorable climate at companies which facilitates creation and implementation of innovations requires new corporate culture based on democratic style of enterprise's management;

- increase of qualification of human resources with modernization of production technologies - enterprises should invest into increase of qualification of their employees, so they could acquire new production technologies. 
The research is limited by its theoretical character. That's why a perspective direction of conduct of further research in the sphere of development of human resources is absence of approbation of the results of the research and developed recommendations by the example of specific enterprises.

\section{References}

Acemoglu, D., Gallego, F.A., Robinson, J.A. (2014). Institutions, human capital, and development. Annual Review of Economics, 6(1), 875-912.

Berge, L.I.O., Bjorvatn, K., Tungodden, B. (2015). Human and financial capital for microenterprise development, Evidence from a field and lab experiment. Management Science, 61(4), 707-722.

Cheng, I.-H., Chan, S.-J. (2015). Aid for human resource development: The rise of Asia( Book Chapter). Routledge Handbook of International Education and Development, 416-427.

CRANET Survey on Comparative Human Resource Management. International Executive Report 2014 (2015). CRANET.

Ciobotaru, A.V., Anghelută, P.S. (2014). Human capital in context of sustainable development. Quality - Access to Success,15 (1), 417421

Dhar, R.L. (2015). The effects of high performance human resource practices on service innovative behavior. International Journal of Hospitality Management, 51, 67-75.

Lauder, H. (2015) Human capital theory, the power of transnational companies and a political response in relation to education and economic development. Compare, 45(3), 490-493.

Li, Y., Zhang, G., Yang, X., Li, J. (2015). The influence of collectivist human resource management practices on team-level identification. Source of the International Journal of Human Resource Management, 26(14), 1791-1806.

Manafi, M., Subramaniam, I.D. (2015). Balancing performance by human resource management practices. Source of the Asian Social Science, 11(10), 386-400.

Oh, H.S., Seo, D.I., Kim, J.S., Yoo, S.O., Seong, H.C. (2015). Assessment and evaluation of national human resource development system competitiveness in emerging countries. Asia Pacific Education Review, 16 (3), 477-490.

Perna, L.W., Orosz, K., Gopaul, B., (...),Ashirbekov, A., Kishkentayeva, M. (2014). Promoting Human Capital Development, A Typology of International Scholarship Programs in Higher Education. Educational Researcher, 43(2), 63-73

Popkova, E.G., Abramov, S.A., Ermolina,L.V., Gandin, E.V. (2015b). Strategic Effectiveness Evaluation as Integral Part of the Modern Enterprise Management. Asian social science, 11(20), 16-21.

Popkova, E.F., Chechina, O.S., Abramov S.A. (2015a). Problem of the Human Capital Quality Reducing in Conditions of Educational Unification. Mediterranean Journal of Social Sciences, 6(3), 95-100.

Popkova, E.G. \& Tinyakova V.I. (2013a). New Quality of Economic Growth at the Present Stage of Development of the World Economy. World Applied Sciences Journal, 5, 617-622.

Popkova, E.G. \& Tinyakova, V.I. (2013b). Drivers and Contradictions of Formation of New Quality of Economic Growth. Middle-East Journal of Scientific Research, 11, 1635-1640.

Popkova, E.G., S.S. Morkovina, E.V. Patsyuk, E.A. Panyavina \& Popov, E.V. (2013). Marketing Strategy of Overcoming of Lag in Development of Economic Systems. World Applied Sciences Journal, 5, 591-595.

Popkova, E.G., Abramov, S.A., Chechina, O.S. (2015a). Problem of the Human Capital Quality Reducing in Conditions of Educational Unification // Mediterranean Journal of Social Sciences / E.G.Popkova, S.A. Abramov, O.S. Chechina. - 2015. - № 6 (3). - P. 95100.

Stone, D.L., Deadrick, D.L., Lukaszewski, K.M.,Johnson, R. (2015). The influence of technology on the future of human resource management. Human Resource Management Review, 25 (2), pp. 216-231.

Sverdlova, Y. (2014). Influence of human capital development on competitiveness of the EU economy. Economic Annals-XXI, 7(8), 1215.

The JSE Socially Responsible Investment (SRI) Index promotes sustainable and transparent business practicesю (2014). JSE SRI Annual Review Results.

Ugheoke, S.O., Isa, M.F.M., Mohd Noor, W.S.W. (2015). Antecedents of strategic human resource management practices on intangible firm performance, Analytical investigation of SMEs. Asian Social Science, 11(13), 33-44. 